Joanna Kowalczyk •

Uniwersytet Jana Kochanowskiego, Kielce

joanna.kowalczyk@ujk.edu.pl

\title{
FUNKCJONALNOŚĆ POJĘĆ TEMPORALNYCH W DYSKURSIE PRAWNYM I URZĘDOWYM
}

Słowa klucze: język prawny, dyskurs urzędowy, czas, nomenklatura

Keywords: legal language, public administration discourse, time, nomenclature

\section{Wstęp}

Powszechne refleksje naukowe i zdroworozsądkowe głoszą, że język tekstów prawnych, rozumiany jako styl aktów normatywnych, to hermetyczny i skomplikowany socjolekt ustawodawcy, niedostępny dla ogółu społeczeństwa. Odnosząc się do stylu formułowania prawa, autorzy różnych opracowań piszą m.in.: „stanowi niekiedy przeszkodę nie do pokonania” (Tumidalski 2016: 15), „jasność i zrozumiałość prawa są od wieków, niczym legendarny Graal, obiektem pożądania wielu ludzi” (Sobieszewska 2015: 126), „nagromadzenie fachowych określeń i skomplikowana gramatycznie budowa norm prowadzą do częstej niezrozumiałości wypowiedzi sformułowanej w języku prawnym" (Kocowska-Siekierka 2016: 145).

Jedną z kategorii, która ze względu na złożoność semantyczną przysparza licznych problemów interpretacyjnych, szczególnie nieprofesjonalnym uczestnikom komunikacji prawnej czy urzędowej, jest nazewnictwo oznaczające czas. Składnik czasowości współtworzy komunikacyjną przestrzeń prawną jako jej nieodłączny element. Jest świadomie lub nieświadomie wykorzystywany we wszystkich aktach dyskursywnych, pozwala porządkować znormatywizowaną rzeczywistość specjalistyczną i wyznacza ramy działania. 
Na płaszczyźnie prawnej czas może być rozpatrywany w różnych wymiarach, m.in. jako determinant skuteczności bądź nieskuteczności działania, jako punkt odniesienia, jako moment graniczny itd., dlatego w niniejszym opracowaniu uwaga zostanie poświęcona kategorii czas w kontekście jej potencjału porządkowania interakcji prawnych.

Przedmiotem oglądu uczyniono wyznaczniki czasu w polskich dokumentach legislacyjnych, urzędowych i sądowych.

Celem artykułu jest wyekscerpowanie tekstowych wykładników czasu funkcjonujących w komunikacji prawnej i urzędowej, wskazanie podstawowych funkcji wyodrębnionych grup temporalnych oraz określenie ich specyficznych cech pragmatycznych, które sprawiają, że kategoria czas umożliwia wielokierunkowe porządkowanie rzeczywistości pozajęzykowej.

Podstawowymi materiałami źródłowymi, z których korzystano, były akty normatywne: Kodeks cywilny (KC), Kodeks postępowania cywilnego (KPC), Kodeks karny (KK), Kodeks postępowania karnego (KPK), Kodeks postępowania administracyjnego (KPA), oraz dokumenty administracyjne i sądowe, m.in. zawiadomienia, zeznania o wysokości osiągniętego dochodu / poniesionej straty w roku podatkowym, informacje o dochodach oraz pobranych zaliczkach na podatek dochodowy, decyzje, nakazy płatnicze, wyroki sądów, postanowienia.

Metodologiczna podstawa prowadzonej analizy miała charakter dwustopniowy. Pierwszy stopień odnosił się do kryterium pragmatycznego, umożliwiającego interpretowanie tekstu jako narzędzia realnie kształtującego rzeczywistość pozajęzykową. Na jego podstawie izolowano poszczególne cząstki tekstów, funkcjonalnie odpowiadające kategorii językowych wyznaczników temporalności. Następnie dokonywano językowo-systemowej wykładni - wyabstrahowane jednostki nazewnicze objaśniano zgodnie $\mathrm{z}$ ich znaczeniem $\mathrm{w}$ dyskursie prawnym/urzędowym. To oznaczało, że rozpatrywano je przez pryzmat zarówno przepisów prawnych, jak i tekstów okołoprawnych, budujących wspólny horyzont pragmatyczny (por. Zieliński i in. 2009).

\section{Specyfika korzystania z kategorii czas w komunikacji prawnej i urzędowej}

Sfera komunikowania prawnego z powodu swej sformalizowanej struktury jest poddana szczególnie ścisłemu reżimowi terminów ${ }^{1}$, określających czasowe granice działania. Jak zauważa Marta Soniewicka, społeczeństwa funkcjonujące w państwach zorganizowanych według zasad prawa nauczyły się, że przewidywalność jest pożądaną właściwością, ponieważ buduje stabilność przyszłości jako bytu znanego

1 Leksem termin w przywoływanym artykule był używany wyłącznie w znaczeniu miary czasu. Nie występował jako ogólna nazwa pojęć specjalistycznych właściwych dla konkretnej dziedziny. 
i spodziewanego. Taką przewidywalność pozwala kształtować m.in. rygor czasowy (2018: 48).

W dyskursach sformalizowanych elastyczność temporalną wypiera porządek wyznaczany przez daty. Od terminowości podejmowanych działań uzależniona jest ich skuteczność prawna (por. Sikora 2017). Podstawowa linia czasu w komunikacji prawnej opiera się na sekwencji: termin - bieg terminu - uplyw terminu. W pierwszym etapie powstaje obowiązek lub prawo, podlegające wykonaniu lub realizacji w określonym czasie, np. powstanie obowiązku złożenia korekty zeznania podatkowego, por.:

Naczelnik Urzędu Skarbowego [...] w związku z błędnym zeznaniem rocznym PIT-37 za rok 2017 - błędne wypełnienie od pozycji 112 prosi o złożenie w terminie $7 \mathbf{d n i}^{2}$ od dnia otrzymania wezwania korekty zeznania podatkowego PIT-37 za rok 2017 (Wezwanie 2018) 2 .

Drugi etap może być prosty lub złożony. W optymalnym wariancie powstanie obowiązku uruchamia bieg terminu, który upływa zgodnie z harmonogramem i kończy się w wyznaczonym dniu / o określonej godzinie. W sytuacji złożonej bieg terminu prawnego nie pokrywa się z biegiem czasu kalendarzowego. Czas kalendarzowy jest nieprzerywalny, „zegar prawny” może zostać wstrzymany, por.:

Zawieszenie postępowania wstrzymuje bieg terminów przewidzianych w kodeksie (art. $103 \mathrm{KPA}$ ).

$\mathrm{W}$ takich warunkach data wskazana na początku biegu terminu jako moment jego upływu zostaje przesunięta na osi czasu w przyszłość. Chwilę upływu terminu w niektórych wypadkach ściśle uzależnia się więc od okoliczności.

Szczególną kategorią temporalną w ramach komunikacji prawnej, na którą należy zwrócić uwagę, jest również możliwość „cofania czasu”, nazywana przywróceniem terminu. Kategoria ta jest ściśle związana z brakiem oczekiwanej aktywności ze strony podmiotu prawa $\mathrm{w}$ ramach postępowania przed sądem lub instytucjami publicznymi (uchybienie terminom). To umowne przyjęcie, że czynności dokonane po upływie wyznaczonego terminu będą potraktowane tak, jakby wykonano je $\mathrm{w}$ odpowiednim czasie. Zastosowanie przywileju przywrócenia terminu następuje jedynie w uzasadnionych wypadkach (Muzyczka 2015: 52), ale sam fakt, że ustawodawca przywraca, a nie wydłuża czas, sugeruje, że elastyczność temporalną w interakcjach prawnych reglamentuje się, chociażby w wymiarze formalnym.

Warto zwrócić również uwagę na to, że jedną z podstawowych form korzystania w komunikacji prawnej z terminu jako daty granicznej jest stosowanie go w kontekście groźby, por.:

2 Wszystkie podkreślenia są odautorskie.

3 Wszystkie wykorzystane $\mathrm{w}$ artykule cytaty zostały przywołane w postaci niezmienionej. Nie ingerowano w ich strukturę gramatyczną, stylistyczną czy interpunkcyjną. 
Niezapłacony w terminie podatek staje się zaległością i podlega wraz z odsetkami za zwłokę egzekucji administracyjnej (Decyzja 2017);

W przypadku niewpłacenia w obowiązującym terminie kwoty z poz. 128 [...] niniejsze zeznanie stanowi podstawę do wystawienia tytułu wykonawczego [...] (PIT-37).

Już na podstawie powyższych refleksji można zauważyć, że w polskim dyskursie prawnym czas stanowi instrument regulowania relacji społecznych. Jest narzędziem zarówno wpływania poprzez perswazyjne wskazanie terminu wykonania narzuconych czynności (np. w ciągu 14 dni) czy zagrożenie karą, jak i formą darowania niesubordynacji wobec zaleceń (przywrócenie terminu). Czas w tym typie interakcji biegnie zgodnie z prawnymi wskazówkami i oprócz tego, że można go formalnie cofnąć, to można go również zatrzymać (wstrzymanie biegu terminu).

\section{Termin jako podstawowa jednostka leksykalna nazywająca czas}

Ważność kategorii temporalności w polskiej sferze prawnej potwierdził szeroki katalog pojęć odnoszących się do czasu, które wprowadził ustawodawca oraz którymi posługują się podmioty władzy administracyjnej i sądowniczej. Podstawową językową formą funkcjonowania czasu w komunikacji formalnej jest termin jako oznaczenie konkretnej lub przybliżonej granicy czasowej. Na tej płaszczyźnie można wyróżnić trzy spetryfikowane formalnie i znaczeniowo klasy terminów: odsyłające do źródła, odsyłające do cechy i odsyłające do funkcji, oraz klasę kolokacyjną, odsyłającą do okoliczności konkretnych zdarzeń. Pierwsze trzy rodzaje terminów mają charakter uogólniony, natomiast ostatni typ odznacza się bliskością z desygnatem ukonkretnionym.

Podczas prowadzonego oglądu ustalono, że jednostki nazywające czas odwołujące się do źródła wprowadzającego zakresy temporalne albo nawiązywały do podmiotu, od którego pochodziła regulacja, albo wskazywały tekst, z którego zostały zaczerpnięte. Przykładami dla pierwszego typu były grupy nominalne termin sadowy czy termin urzędowy. W obu wypadkach proweniencja nazw korespondowała z semantyką pojęć. Termin sądowy oznacza bowiem czas wyznaczony przez sąd na wykonanie określonych czynności w ramach prowadzonego postępowania, a termin urzędowy to czas wskazany przez organ administracji publicznej (urząd) jako okres na wykonanie obowiązków czy realizację praw. Oprócz źródeł podmiotowych w nazwach terminów pojawiały się również odniesienia do źródeł tekstowych, np. do ustaw czy umów. Za przykłady mogą posłużyć wyrażenia termin ustawowy i termin umowny. Termin ustawowy odsyła do źródła będącego powszechnie obowiązującym aktem normatywnym, z kolei termin umowny wskazuje na dobrowolne porozumienie stron jako podstawę wprowadzenia regulacji czasowych.

Kolejną grupę tworzyły wyrażenia odsyłające do cechy terminu, właściwe dla takich jednostek, jak termin stanowczy, termin prekluzyjny czy termin zawity. Wszyst- 
kie nazwy odsyłają do determinantów ontologicznych. W nazwie termin stanowczy podkreślona została istotność cezury. Fundamentem pojęcia termin zawity jest reżim czasowy - „zawitość” jako cecha czasu powoduje, że wszelkie czynności dokonane po upływie takiego terminu są nieważne z perspektywy prawnej, choć w wyjątkowych sytuacjach umożliwia się przywrócenie terminu zawitego (Nowak 2015: 233). Natomiast termin prekluzyjny opiera się na wyróżnieniu znaczenia "prekluzji” jako czasu ostatecznego, po którego przekroczeniu następuje definitywne zakończenie sprawy, ponieważ prekluzja eliminuje przywilej przywrócenia terminu (por. m.in.: Waltoś 2001: 45; Kasprzyk, Wasiak 2002: 193).

Kolejnym rodzajem nazw temporalnych były przykłady zawierające odniesienia do funkcji pełnionej przez termin, np. termin instrukcyjny, występujący również $\mathrm{w}$ wariancie termin porządkowy. Jak można zauważyć, człon określający bezpośrednio odwołuje się do wykorzystania terminu. W tym wypadku jednocześnie sugeruje jego znaczenie jako orientacyjnego czasu, w którym najprawdopodobniej zostanie rozstrzygnięty problem prawny.

Ostatnią, najmniej sformalizowaną grupę nazewniczą stanowiły przykłady określania granic czasowych poprzez odwołania do przedmiotu aktualnej regulacji, zdeterminowanej okazjonalnymi okolicznościami i warunkami. Kolokacyjny sposób werbalizowania jednostek temporalnych właściwie był nieograniczony, ponieważ przykłady w tej grupie wyróżniały się dowolnością połączeń przydawkowych, uzależnioną jedynie od przedmiotu dyskursu, np. termin wniesienia odwołania; termin zapłaty; termin wygaśnięcia ochrony. Łączliwość w tej grupie miała luźny charakter i dopuszczała różnorodne modyfikacje, m.in. przyimkowe: termin wniesienia odwołania, termin na wniesienie odwołania, termin do wniesienia odwołania, czy leksykalne: termin zapłaty; termin płatności. Należy również zauważyć, że w odróżnieniu od poprzednich typów oznaczania czasu przykłady przyporządkowane do tej klasy odnosiły się zarówno do okresów (np. termin do złożenia zażalenia), jak i do konkretnych dat (np. termin wygaśnięcia umowy).

\section{Specyfika niedookreśloności temporalnej}

Chociaż polski dyskurs prawny charakteryzuje się czasowym uporządkowaniem poszczególnych etapów komunikacji (por. Ablewicz, Gacka-Asiewicz 2016), to pośród precyzyjnych wskazań typu nie później niż 20 kwietnia, w ciagu miesiąca, na okres 3 lat itd. funkcjonują także niedookreślone formy językowe, np. w trybie planowym, $w$ trybie przyśpieszonym, $w$ trybie pilnym, w trybie natychmiastowym.

Wyrazisty przykład stosowania zwrotów uogólnionych nazywających zjawiska temporalne ilustruje triada natychmiast - niezwłocznie - bez zbędnej zwłoki - szeroko wykorzystywana w komunikacji sformalizowanej. Po pierwsze wskazane exempla są wyrazem stosowania uogólnionych ram czasowych. Po drugie zwracają uwagę 
na to, że nie tylko terminowość (do kiedy?, w jakim czasie?), ale również tempo (jak $s z y b k o$ ?) działań podlega regulacji. Po trzecie uwidaczniają fakt, że w dyskursie prawnym szczegóły znaczeniowe determinują istotę zjawisk temporalnych. Wszystkie wskazane zakresy czasowe odnoszą się do sprawności działania w obrębie sfery prawnej. Nie należy ich jednak utożsamiać, ponieważ każda z jednostek nominatywnych w ramach dyskursu prawnego wiązała się z innym natężeniem aktywności. Ze względu na fakt, że żadna $\mathrm{z}$ wymienionych nazw, tj. natychmiast, niezwłocznie i bez zbędnej zwłoki, nie ma definicji legalnej (wskazanej w akcie prawnym), dokonano analizy przykładów użycia wszystkich tych form w tekstach prawnych i prawniczych, aby ustalić ich właściwą (funkcjonalną) semantykę.

Na postawie analizy kontekstów użyć ustalono, że natychmiast ma najwyższy współczynnik szybkości działania, tj. cechy reakcji odruchowych. Włączając do bazy leksykalno-semantycznej tę formę tempa działań, polski ustawodawca ukonstytuował prawo do wykonywania pewnych czynności automatycznie, bez konsultacji merytorycznych i formalnych. Ze względu na swą specyfikę jest to kategoria dotycząca przede wszystkim działań faktycznych (fizycznych), od których zależą najważniejsze wartości, np. ochrona życia i zdrowia, obrona mienia, por.:

Posiadacz rzeczy ruchomej, jeżeli grozi mu niebezpieczeństwo niepowetowanej szkody, może natychmiast po samowolnym pozbawieniu go posiadania zastosować niezbędną samopomoc w celu przywrócenia stanu poprzedniego (art. 343 ust. 2 KC).

$\mathrm{W}$ toku porównywania tekstowej - a tym samym i realnej - funkcji sformułowań natychmiast i niezwłocznie zauważono, że określenie niezwłocznie w odniesieniu do pojęcia natychmiast traci przymiot reakcji odruchowej. Niezwłocznie to nie 'w tej samej chwili', lecz 'szybko, w najbliższym terminie, w którym można coś wykonać. Niezwłocznie funkcjonuje zarówno w odniesieniu do działań faktycznych, jak i formalnych, por.:

[tempo działań formalnych] Niezwłocznie powinny być rozpatrzone sprawy, które mogą być rozpatrzone w oparciu o dowody przedstawione przez stronę [...] (art. 35 ust. $2 \mathrm{KPA}$ );

[tempo działań faktycznych] Pozwany niezwłocznie zgodnie z obowiązującymi w tym zakresie przepisami opróżnił lokal mieszkalny faktycznie się z niego wyprowadzając (II Ca 794/14).

W niektórych wypadkach owa niedookreśloność temporalna podlegała doprecyzowaniu poprzez podanie końcowej granicy czasu, do której można uznać tempo działania za niezwłoczne, por.:

[...] w przypadku, w którym dotychczasowy właściciel lub użytkownik wieczysty nieruchomości [...] wyda tę nieruchomość niezwłocznie, lecz nie później niż w terminie 30 dni od dnia w którym decyzja [...] stała się ostateczna [...] (Zawiadomienie 2017). 
Z kolei analiza kontekstów wykorzystywania jednostki nazewniczej bez zbędnej $z w ł o k i$ wykazała, że wyrażenie to, określające tempo wykonywanych czynności, odnosi się do zracjonalizowanego trybu postępowania, uwzględniającego wszystkie okoliczności mogące wstrzymać lub spowolnić postęp, por.:

Organy administracji publicznej obowiązane są załatwiać sprawy bez zbędnej zwłoki (art. 35 ust. $1 \mathrm{KPA})$;

[...] przy ocenie czy doszło do naruszenia prawa strony do rozpoznania sprawy bez zbędnej zwłoki, należy w szczególności ocenić terminowość i prawidłowość czynności podjętych przez sąd $\mathrm{w}$ celu wydania w sprawie rozstrzygnięcia, uwzględniając charakter sprawy, stopień faktycznej i prawnej jej zawiłości [...] (II S 21/17).

$\mathrm{W}$ odniesieniu do poprzedniej jednostki, tj. niezwłocznie, omawiana kategoria bazowała na obecności, braku lub ustaniu przeszkód bezpośrednio lub pośrednio oddziałujących na proces wykonywanych działań / podejmowanych rozstrzygnięć.

Rozpatrując kwestię tempa w kontekście afirmowanego miernika czasu w polskim dyskursie oficjalnym, warto zwrócić również uwagę na to, że nie tylko sprawność działania podlega regulowaniu normatywnemu, ale także niewłaściwe wykorzystywanie czasu poprzez dopuszczenie do nieuzasadnionej zwłoki (przewlekłości postępowania), por.:

Strona może wnieść skargę o stwierdzenie, że [...] nastąpiło naruszenie jej prawa do rozpoznania sprawy bez nieuzasadnionej zwłoki [...], jeżeli postępowanie [...] trwa dłużej niż to konieczne [...] (art. 2 ust. 1 SNPS);

Stronie służy prawo do wniesienia ponaglenia, jeżeli: [...] postępowanie jest prowadzone dłużej niż jest to niezbędne do załatwienia sprawy [...] (art. 37 ust. 1 pkt $2 \mathrm{KPA})$.

W powyższych przykładach ujęto przewlekłość jako aberrację temporalną. Przywołane fragmenty wskazują, że czas w tej sferze interakcji jest wyznacznikiem jakości, a niewłaściwe nim rozporządzanie - składnikiem niepożądanym, godzącym w zasadę efektywności państwa prawa i jego organów.

\section{Złożoność jednostek temporalnych a prawidłowa interpretacja ich znaczenia}

Dyskurs prawny (sądowy, urzędowy itp.) właściwie w każdym swym praktycznym przejawie opiera się na granicach czasowych. Jak zostało przedstawione w poprzednich częściach artykułu, odniesienia temporalne mogą być ścisłe (np. do 30 kwietnia) lub uogólnione (np. bez zbędnej zwłoki). Co do zasady ścisły zakres w tym typie komunikowania oznaczany jest w podstawowych jednostkach miary czasu, tj. w dniach, tygodniach itd. Zdarzają się również określenia wyjątkowe, wyznacza- 
ne granicami godzinowymi. Do takich wyjątków zalicza się m.in. wskazanie terminu żałoby narodowej w Polsce, która może być podana z zaznaczeniem godziny jej rozpoczęcia i zakończenia (por. RPRP 2019). Są to jednak sytuacje szczególne.

Specyfika operowania zakresem temporalnym w polskim dyskursie oficjalnym zakłada przede wszystkim wykorzystywanie przedziałów dziennych, tygodniowych, miesięcznych, rocznych oraz ich cząstek (np. pół miesiąca).

Odnotowano, że konceptualizowanie rzeczywistości temporalnej za pomocą jednostek dziennych odbywa się dwubiegunowo. Po pierwsze w tekstach wskazywana jest konkretna data, stanowiąca punkt odniesienia, por.:

[data końcowa] TERMIN PŁATNOŚCI 22.03.2019 (F/40344759/03/19);

[data początkowa] [...] za opóźnienie od dnia 2018-02-23 [...] (VI Nc-e 1826039/18).

Po drugie stosuje się spetryfikowane formuły wyznaczające, z ilu jednostek dziennych składa się określony etap prawny, por.:

Dłużnik ma obowiązek zawiadamiać komornika w terminie 7 dni o każdej zmianie miejsca swego pobytu trwającej dłużej niż miesiąc (art. $761 \$ 1$ KPC, cyt. za: Pouczenie dłużnika 2019).

O ile przykłady, w których nadawca posługuje się konkretną datą, nie sprawiają większych trudności interpretacyjnych, o tyle w drugim wypadku można mieć wątpliwości, w jaki sposób obliczyć 7 dni, 14 dni, 30 dni itd. Zgodnie z założeniami prawodawczymi (art. $111 \mathrm{KC}$, art. $57 \$ 1 \mathrm{KPA}$ ) terminy oznaczane w jednostkach dziennych (np. 7 dni) należy obliczać według uproszczonego wzorca:

Ryc. 1. Bieg terminu oznaczonego w dniach

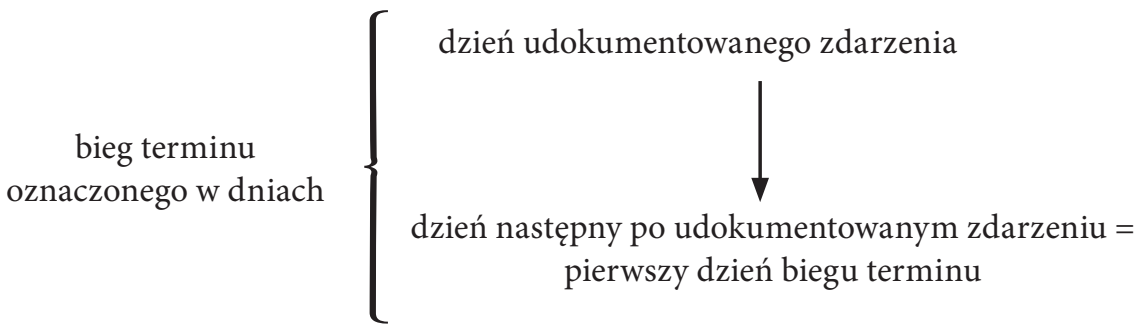

Przykład mogący wyjaśnić niezrozumiałe kwestie ilustruje sytuacja z otrzymaniem listu poleconego, który doręczono, a jego odbiór pokwitowano 6 marca. W otrzymanym piśmie adresat został zobligowany do wykonania pewnych czynności w terminie 7 dni od daty otrzymania pisma. Tak wskazany okres w tym wypadku obejmuje przedział od 7 do 13 marca, nie zaś od 6 do 12 marca. Wypadkiem szczególnym jest jednak sytuacja, gdy 13 marca, tj. ostatni dzień na załatwienie sprawy, oka- 
zał się dniem wolnym od pracy, np. świętem państwowym. Wtedy siedmiodniowy termin zostaje automatycznie wydłużony do najbliższego dnia roboczego. Jeśli więc 13 marca byłby piątkiem, na który przypadałby dzień ustawowo wolny (lub sobotą por. Pieróg, Marciniak 2016), to 7 dni „urzędowych” równałoby się 9 lub 10 dniom kalendarzowym, ponieważ ostatnim, formalnie 7 dniem, byłby poniedziałek ( 15 lub 16 marca). Istotną informacją wpływającą na poprawność interpretacji temporalnej jest również fakt, że przesunięcie terminu powiązane $\mathrm{z}$ dniem ustawowo wolnym od pracy nie następuje, gdy dzień wolny wypadnie w dniu innym niż ostatni dzień biegu terminu, np. w trzecim czy czwartym.

Na określenie czasu w dyskursie prawnym wykorzystuje się także uogólnione jednostki temporalne typu tydzień, miesiac, rok, por.:

Skargę wnosi się do sądu w terminie tygodniowym od dnia doręczenia stronie postanowienia referendarza sądowego, chyba że przepis szczegółowy stanowi inaczej (Pouczenie dłużnika 2019);

Starszy referendarz sądowy [...] nakazuje pozwanemu [...] w ciągu dwóch tygodni od doręczenia nakazu zapłacić powodowi [...] (VI Nc-e 1826039/18);

Sprzedawca odpowiada za niezgodność towaru konsumpcyjnego z umową jedynie w przypadku jej stwierdzenia przed upływem dwóch lat od wydania tego towaru [...] (art. 10 ust. 1 SWSK).

Interesującą kwestią $\mathrm{w}$ tym obszarze okazała się relacja między dziennymi i uogólnionymi sposobami nazywania określonych przedziałów czasowych (np. $7 d n i$ vs. tydzień, 30 dni vs. miesiąc itd.) a semantyką terminów.

Zgodnie z polskim prawodawstwem (art. $112 \mathrm{KC}$; art. $57 \$ 2 \mathrm{KPA}$ ) termin tygodniowy to okres obejmujący czas wyznaczony przez tę samą nazwę dnia, np. od wtorku do wtorku, od środy do środy itd. Praktycznie więc ustawowy tydzień to ustawowe siedem dni, choć formalnie tydzień trwa dłużej niż siedem dni, ponieważ bieg terminu tygodniowego rozpoczyna się $\mathrm{w}$ dniu zdarzenia, a nie $\mathrm{w}$ dniu następnym.

Nieco bardziej skomplikowana jest kwestia ustalania terminu miesięcznego, ponieważ w miesiącu może być 28,29 , 30 lub 31 dni. Ustawodawca założył dwie możliwości. Po pierwsze miesiąc wyznaczają granice tych samych dat w kolejnych miesiącach (art. $112 \mathrm{KC}$; art. $57 \$ 3 \mathrm{KPA}$ ), np. od 5 listopada do 5 grudnia, od 10 stycznia do 10 lutego itd. Problem pojawia się, gdy w kolejnym miesiącu nie ma daty-odpowiednika, np. gdyby początkiem terminu był 31 stycznia, to w lutym nigdy nie będzie takiej daty. W takich wypadkach termin miesięczny kończy się ostatniego dnia miesiąca (dla powyższego przykładu ostatniego dnia lutego, czyli termin miesięczny liczyłby 28 lub 29 dni). Po drugie w sytuacjach, w których nie jest konieczna ciągłość czasowa, formalnie ustanowiono, że miesiąc to 30 dni (art. $114 \$ 1 \mathrm{KC}$ ). Jeśli zaś czas zostanie określony ułamkowo - pót miesiąca - oznacza to 15 dni (art. $113 \$ 2 \mathrm{KC}$ ), co de facto nie zawsze odpowiada rzeczywistej/kalendarzowej połowie miesiąca. Po 
trzecie termin można wyznaczyć na początek, środek i koniec miesiąca. Polski ustawodawca doprecyzował, że początek oznacza jego pierwszy dzień, a koniec - ostatni. Natomiast środek miesiąca to jego piętnasty dzień - niezależnie od tego, ile dni liczy miesiąc (art. $113 \$ 1 \mathrm{KC}$ ).

Termin wyznaczony w latach określa się analogicznie do terminu miesięcznego rok kończy się w dniu odpowiadającym datą dzienną i nazwą miesiąca dniowi, który został wskazany jako początek terminu. Jeżeli w ostatnim miesiącu rocznego terminu nie ma daty-odpowiednika, koniec terminu wypada w ostatni dzień tego miesiąca (art. $112 \mathrm{KC)} / \mathrm{w}$ dzień bezpośrednio poprzedzający zakładaną datę końcową (art. $57 \$ 3 a \mathrm{KPA})$, np. jeśli początek rocznego terminu wyznaczony został datą 29 lutego, to koniec wypada 28 lutego następnego roku. W sytuacjach, w których nie jest konieczna ciągłość czasowa, formalnie ustanowiono, że rok to $365 \mathrm{dni}$ (art. $114 \mathrm{KC}$ ).

\section{Zakończenie}

Analiza tekstowych wykładników temporalności w dyskursie prawnym i urzędowym wykazała, że czas to jeden z podstawowych elementów kształtujących specyfikę organizowania komunikacji oficjalnej. Poddając oglądowi zarówno teksty normatywne (ustawy), jak i dokumenty implementujące ich założenia (akty sądowe, dokumenty urzędowe), zauważono szeroką funkcjonalność jednostek nazywających czas. Specyfika temporalności w tej sferze opiera się na szczególnym sposobie rozumienia czasu. Przestał być on niezależnym bytem, a został ujęty w ściśle skonwencjonalizowane ramy funkcjonalne - spełnienie określonych warunków pozwala na jego zatrzymywanie (wstrzymanie biegu terminu) lub cofanie (przywrócenie terminu), czas może być też instrumentem pozwalającym na realizowanie swych praw (np. prawo do wniesienia odwołania w określonym terminie) lub narzędziem perswazji (np. wskazanie terminu zapłaty pod groźbą wyciągnięcia konsekwencji prawnych).

W badanych tekstach odnotowano utrwalone konstrukcje nazewnicze wiążące wyznacznik temporalny z jego źródłem (np. termin ustawowy), atrybutem (np. termin zawity) i funkcją (np. termin instrukcyjny). Wyodrębniono również przykłady o strukturze otwartej, okazjonalnej (np. termin zapłaty/płatności).

W toku analiz zauważono, że sposoby oznaczania czasu można sklasyfikować albo jako uogólnione (np. $w$ trybie pilnym), albo jako precyzyjne (np. do 15 maja). Zwrócono uwagę na to, że wyznaczniki czasu w dyskursach oficjalnych nie były jedynie formą oznaczenia terminu, ale również sposobem na określenia tempa działania. Tę kategorię opisano na podstawie niedookreślonych jednostek temporalnych, takich jak: natychmiast, niezwłocznie czy bez zbędnej zwłoki - których semantyczne właściwości z jednej strony ukazały hermetyczność znaczeniową nomenklatury specjalistycznej, z drugiej wskazały na potrzebę stratyfikacji szybkości działania. 
Ostatnia część badania została poświęcona formalnej i rzeczywistej semantyce zakresów temporalnych. Scharakteryzowano pod tym kątem ustawowo wprowadzone przedziały oznaczane $\mathrm{w}$ dniach, tygodniach, miesiącach i latach. Ustalono, że język prawny wprowadza wyspecyfikowaną interpretację tych okresów, co powoduje, że granice kalendarzowe czy zwyczajowe nie muszą pokrywać się z czasowymi granicami prawnymi.

\section{Źródła}

II Ca 794/14: Wyrok Sądu Okręgowego w Piotrkowie Trybunalskim z dn. 30 grudnia 2014 r., syg. akt II Ca 794/14.

II S 21/17: Postanowienie Sądu Apelacyjnego we Wrocławiu z dn. 26 września 2017 r., Wrocław, syg. akt II S 21/17.

VI Nc-e 1826039/18: Nakaz zapłaty w postępowaniu upominawczym z dn. 16 listopada 2018 r., Lublin, syg. akt VI Nc-e 1826039/18.

Decyzja 2017: Decyzja z dn. 10.01.2017 roku w sprawie określenia wysokości stawek podatku od nieruchomości, Kielce, nr P-I.3120.1.0150.1638.2.2017.

F/40344759/03/19: Faktura za usługi telekomunikacyjne z dn. 8 marca 2019 r., Warszawa.

KC: Kodeks cywilny z dn. 23 kwietnia 1964 r., Dz.U. 1964, nr 16, poz. 93.

KK: Kodeks karny z dn. 6 czerwca 1997 r., Dz.U. 1997, nr 88, poz. 553.

KPA: Kodeks postępowania administracyjnego z dn. 14 czerwca 1960 r., Dz.U. 1960, nr 30, poz. 168.

KPC: Kodeks postępowania cywilnego z dn. 17 listopada 1964 r., Dz.U. 1964, nr 43, poz. 296.

KPK: Kodeks postępowania karnego z dn. 6 czerwca 1997 r., Dz.U. 1997, nr 89, poz. 555.

PIT-37: Formularz zeznania o wysokości osiągniętego dochodu (poniesionej straty) w roku podatkowym, [on-line] https://www.podatki.gov.pl/pit/e-deklaracje-pit/dla-osob-nieprowadzacych-dzialalnosci-gospodarczej/\#PIT-37 (dostęp: $20 \mathrm{~V}$ 2020).

PouCZENIE DŁUŻNIKA 2019: Wzór tytułu wykonawczego / zajęcia komorniczego za rok 2019.

RPRP 2019: Rozporządzenie Prezydenta Rzeczypospolitej Polskiej z dn. 17 stycznia 2019 r. w sprawie wprowadzenia żałoby narodowej na terytorium Rzeczypospolitej Polskiej, Dz.U. 2019, poz. 107.

SNPS: Ustawa z dn. 17 czerwca 2004 r., o skardze na naruszenie prawa strony do rozpoznania sprawy w postępowaniu sądowym bez nieuzasadnionej zwłoki, Dz.U. 2004, nr 179, poz. 1843.

SWSK: Ustawa z dn. 27 lipca 2002 r. o szczególnych warunkach sprzedaży konsumenckiej oraz zmianie Kodeksu cywilnego, Dz.U. 2002, nr 141, poz. 1176.

WEZWANIE 2018: Wezwanie $\mathrm{z}$ dn. 20.05.2018 roku w sprawie korekty zeznania podatkowego, Busko-Zdrój, nr 2602-SOB.4031.203.2018, 7904/2018.

ZaWIADOMIENIE 2017: Zawiadomienie o zezwoleniu na realizację inwestycji drogowej z dn. 9.01.2017 r., Kielce, nr SPN.III.7820.1.8.2016. 


\section{Literatura}

Ablewicz J., Gacka-Asiewicz A., 2016, Terminy ustawowe cywilne i karne, wyd. 2, Warszawa.

KASPRZYK P., WASIAK M., 2002, Terminy prekluzyjne na gruncie kodeksu rodzinnego i opiekuńczego, „Studia z Prawa Wyznaniowego” IV, s. 191-204.

Kocowska-Siekierka E., 2016, Prawo do dobrej administracji - w kierunku upraszczania języka urzędowego w Polsce i $w$ Czechach, „Przegląd Prawa i Administracji” CVII, s. $145-163$.

MuzyczKa K., 2015, Przywrócenie terminu w postępowaniu administracyjnym, „Acta Universitatis Lodziensis. Folia Iuridica" 75, s. 51-72.

NowaK I., 2015, Uprawdopodobnienie braku winy jako przesłanka zasadności wniosku o przywrócenie terminu $w$ świetle ordynacji podatkowej, na tle orzecznictwa sadów administracyjnych, [w:] R. Dowgier (red.), Ordynacja podatkowa. Stan obecny i kierunki zmian, Białystok, s. 229-249.

Pieróg J., Marciniak M., 2016, Obliczanie terminów, „Przetargi Publiczne” nr X, s. 50-53. Sikora P., 2017, Poradnik prawny. Terminy urzędowe i sądowe, red. K. Dziuba, [on-line:] http://dogma.org.pl/wp-content/uploads/2017/10/terminy_urzedowe_i_sadowe.pdf (dostęp: 20 VI 2020).

SoBIESZEwSKA M., 2015, Juryslingwistyka: między językiem a prawem, „Studia Iuridica Lublinensia" XXIV, nr 4, s. 123-131.

SoniewickA M., 2018, Czas jako kategoria prawna, „Filozofuj!” nr 2 (20), s. 48-49, [on-line:] https://filozofuj.eu/wp-content/uploads/2018/o4/fio2o_net.pdf (dostęp: 2 VI 2020).

Tumidalski W., 2016, Język prawny i prawniczy a język mediów, „Naukowy Przegląd Dziennikarski" nr 2, s. 15-28.

Waltoś S., 2001, Proces karny. Zarys systemu, wyd. 5 zm., Warszawa.

Zieliński M., Bogucki O., Choduń A., Czepita S., Kanarek B., Municzewski A., 2009, Zintegrowanie polskich koncepcji wykładni prawa, „Ruch Prawniczy, Ekonomiczny i Socjologiczny" LXXI, z. 4, s. 23-39.

\section{Functionality of Temporal Concepts in Legal and Public Administration Discourse Summary}

The article is dedicated to the concept of time in the context of its potential to organize legal interactions. The subject of the study includes time markers in Polish legislative, official and court documents. The aim of the article is to describe the temporal terminology used in legal and official communication, and to find pragmatic characteristics that make it possible for the concept of time to organize extralinguistic reality in many different aspects. The author of the article analyses both fixed language constructs and language units with an open and occasional structure. 